\title{
Effect of Known Inhibitors of Ion Transport on Pendrin (SLC26A4) Activity in a Human Kidney Cell Line
}

\author{
Emanuele Bernardinelli Roberta Costa Charity Nofziger Markus Paulmichl \\ Silvia Dossena \\ Institute of Pharmacology and Toxicology, Paracelsus Medical University, Salzburg, Austria
}

\section{Key Words}

Pendrin • Kidney • Airways $•$ Hypertension $•$ Asthma $•$ Niflumic acid $•$ Tenidap

\begin{abstract}
Background/Aims: Pendrin is a $\mathrm{Cl}^{-} / \mathrm{I}^{-} / \mathrm{HCO}_{3}^{-}$exchanger playing a fundamental role in controlling blood pressure and airway function, therefore representing an attractive target for the treatment of hypertensive states and respiratory distresses. A review of the literature regarding the ability of some compounds (namely several known inhibitors of ion transport) to block pendrin activity revealed discordant findings. These incongruous findings may be due, in part, to the concentration of compound and/or the nature of the model system used in the study. Methods: Pendrin activity was evaluated by measuring pendrin-dependent iodide influx following overexpression of the transporter in a human kidney cell line, in the presence of selected test compounds or the respective vehicles. Results: Pendrin activity was significantly hampered by $0.1 \mathrm{mM} 5$-nitro-2-[(3-phenylpropyl)amino]benzoic acid (NPPB),

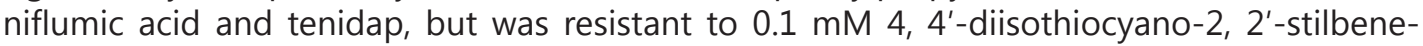
disulfonic acid (DIDS), furosemide and probenecid. Conclusions: The results of the present study indicate that clinically effective non-steroidal anti-inflammatory drugs (niflumic acid and tenidap) directly inhibit pendrin activity.

(C) 2016 The Author(s)

Published by S. Karger AG, Basel
\end{abstract}

\section{Introduction}

Pendrin (solute carrier family 26, member A4; SLC26A4) is an electroneutral, $\mathrm{Na}^{+}-$ independent $\mathrm{Cl}^{-} / \mathrm{I}^{-} / \mathrm{HCO}_{3}{ }^{-}$exchanger of which malfunction leads to forms of sensorineural autosomal recessive syndromic (Pendred syndrome; OMIM ID_274600) [1] or nonsyndromic deafness (DFNB4; OMIM ID_600791) [2], with and without thyroid involvement, respectively. Besides being expressed in the inner ear and thyroid, pendrin is also found in the kidney and airways.

In the kidney, pendrin is localized on the apical membrane of $B$ and non- $A$, non-B intercalated cells of the cortical collecting duct (CCD) and connecting tubule (CNT) [3-5]. The first well characterized function of pendrin in the kidney was the secretion of $\mathrm{HCO}_{3}^{-}$and the control of acid-base balance $[3,6]$. Later, a consistent body of evidence pointed to a significant 


\section{Cellular Physiology Cell Physiol Biochem 2016;38:1984-1998 \\ and Biochemistry Published online: May 09, $2016 \quad \begin{aligned} & \text { DOI: 10.1159/00044559 } 2016 \text { The Author(s). Published by S. Karger AG, Basel } \\ & \text { www.karger.com/cpb }\end{aligned}$ \\ Bernardinelli et al.: Effect of Known Inhibitors of Ion Transport on Pendrin}

role of pendrin in the conservation of $\mathrm{Cl}^{-}[7,8]$ and regulation of blood pressure $[9,10]$. Differences in blood pressure between pendrin null and wild type mice, although not evident in basal conditions, became apparent following dietary $\mathrm{NaCl}$ restriction or aldosterone infusion $[7,11]$. In these settings, pendrin null mice were unable to appropriately conserve $\mathrm{NaCl}$ and, as a consequence of reduced abundance [12], channel surface density and activity [13] of the epithelial sodium channel $(\mathrm{ENaC})$, a major determinant of the aldosterone-dependent, amiloride-sensitive salt reabsorption in the distal nephron, developed hypotension. In addition, pendrin governs an electroneutral, thiazide-sensitive $\mathrm{NaCl}$ reabsorption in tandem with the sodium-driven chloride/bicarbonate exchanger/solute carrier family 4 , member A8 (NDCBE/SLC4A8) [14]. Accordingly, mice overexpressing pendrin develop salt-sensitive hypertension when exposed to a high-salt diet [15]. The role of pendrin in regulating blood pressure is further evidenced in pendrin/sodium-chloride cotransporter (NCC) double knockout mice, as they display severe salt wasting, sharp increases in urine output and profound volume depletion [16]. Overall, these evidences suggest that pendrin gene ablation may be protective against the development of hypertension [9], and that pendrin could be a promising target for diuretic therapy [17-19].

In the airways, increased pendrin expression has been linked to respiratory diseases including bronchial asthma, chronic obstructive pulmonary disease (COPD), rhinovirus infection, rhinitis and chronic rhinosinusitis [20, 21]. Pendrin expression is upregulated in murine models of asthma [22] via an interleukin (IL)-4/13-dependent pathway [23, $24]$, leading to increased mucus production and neutrophilic infiltration [25]. In addition, pendrin-driven $\mathrm{Cl}^{-}$reabsorption can reduce the thickness of the airway surface liquid, therefore worsening airway inflammation and obstruction [26]. Accordingly, pendrin gene transcription was increased in endobronchial biopsies from asthmatic patients [27]. In addition, pendrin was upregulated by IL-17A in human bronchial epithelial cells [28] and lungs of Bordetella pertussis infected mice [29]. The emerging evidence supporting a role of pendrin in the pathogenesis of inflammatory and infectious lung disease indicates that this molecule could be a potential novel therapeutic target for the treatment of respiratory distresses $[20,21]$.

Because pendrin inhibition may represent a novel strategy in the treatment of various disease states, notable effort was devoted to the identification of pendrin blockers. In the absence of an experimentally determined structure [30], structure-based drug design was inapplicable in the difficult task of identifying new pendrin inhibitors. Indeed, very recently, selective pendrin inhibitors, belonging to the tetrahydropyrazolopyridine and pyrazolothiophenesulfonamide classes of compounds, were identified by a high-throughput screen of $\sim 36,000$ synthetic small molecules following pendrin expression in Fischer rat thyroid cells. Among those, PDS $_{\text {inh }}$-A01 increased airway surface liquid volume in IL-13treated airway cell cultures from both healthy subjects and patients affected by cystic fibrosis [31].

A review of the literature regarding the ability of some compounds (namely several known inhibitors of ion transport) to block pendrin activity revealed discordant findings (Table 1). These incongruous findings may be due, in part, to the concentration of compound and/or the nature of the model system used in the study. Here we show the functional screening of relatively low concentrations $(0.1 \mathrm{mM})$ of 22 small molecules on pendrindriven iodide influx following overexpression of human pendrin in a human kidney cell line, performed with the aims of (i) shedding light on previous conflicting results and (ii) confirming previous findings obtained with different techniques and/or model cell systems.

\section{Materials and Methods}

Plasmids

The open reading frame (ORF) of human pendrin from normal thyroid tissue was cloned into the pTARGET (Promega Corporation) vector, originally provided by Prof. P. Beck-Peccoz, University of Milan, 


\begin{tabular}{|c|c|c|}
\hline \multirow{2}{*}{$\begin{array}{l}\text { Cellular Physiology } \\
\text { and Biochemistry }\end{array}$} & \multicolumn{2}{|c|}{ Cell Physiol Biochem 2016;38:1984-1998 } \\
\hline & $\begin{array}{l}\text { Dol: 10.1159/000445559 } \\
\text { Published online: May 09, } 2016\end{array}$ & $\begin{array}{l}\text { O } 2016 \text { The Author(s). Published by S. Karger AG, Basel } \\
\text { www.kargercom/cpb }\end{array}$ \\
\hline
\end{tabular}

Table 1. Compounds tested on pendrin activity. The established target(s) known to be blocked by each compound is (are) reported together with the previously reported (when known) effect on pendrin and the effect observed in the present study. The concentration tested in the present or previous studies was $0.1 \mathrm{mM}$, except where otherwise specified. The concentration of CFTR-inhibitor 172 was $1.6 \mu \mathrm{M}$, suggested by previous reports leading to maximal reduction in the open probability of CFTR [88]. The concentration of eplerenone was $10 \mu \mathrm{M}$, due to poor solubility. CFTR, cystic fibrosis transmembrane conductance regulator; COX, cyclooxygenase; DIDS, 4, 4'-diisothiocyano-2, 2'-stilbenedisulfonic acid; DNDS, 4, 4'-dinitrostilbene-2, 2'-disulfonate; DRA, down-regulated in adenoma; ENaC, epithelial sodium channel; KCNJ1, potassium channel, inwardly rectifying subfamily J, member 1; LOX, lipooxygenase; NCC, sodium chloride cotransporter; NKCC2, sodium potassium chloride cotransporter 2; NPPB, 5-nitro-2-[(3-phenylpropyl)amino] benzoic acid; OAT1, organic anion transporter 1; PLA2, phospholipase A2; SLC26A3, solute carrier family 26 , member A3

\begin{tabular}{|c|c|c|c|}
\hline \multirow[b]{2}{*}{ Test compound } & \multirow[b]{2}{*}{ Conventional target } & \multicolumn{2}{|c|}{ Effect on pendrin } \\
\hline & & $\begin{array}{l}\text { Previous } \\
\text { reports }\end{array}$ & $\begin{array}{c}\text { Present } \\
\text { study }\end{array}$ \\
\hline \multicolumn{4}{|c|}{ Diuretics and antihypertensive agents } \\
\hline Acetazolamide & Carbonic anhydrase [80] & No effect [49] & No effect \\
\hline Amiloride & $\mathrm{ENaC}[81,82]$ & No effect [49] & No effect \\
\hline Bumetanide & NKCC2 [82] & No effect [49] & No effect \\
\hline Chlorothiazide & NCC $[83,84]$ & No effect [49] & No effect \\
\hline Eplerenone & Aldosterone antagonist $[82,85]$ & - & No effect $(10 \mu \mathrm{M})$ \\
\hline \multirow[t]{2}{*}{ Furosemide } & NKCC2 $[82,86]$ & No effect [49] & No effect \\
\hline & & $59 \%$ inhibition (1 mM) [47] & $39 \%$ inhibition $(1 \mathrm{mM})$ \\
\hline Hydrochlorothiazide & NCC $[83,84]$ & No effect [49] & No effect \\
\hline Hydroflumethiazide & NKCC2 [82] & No effect [49] & No effect \\
\hline Indapamide & NCC (?) [84] & No effect [49] & No effect \\
\hline Methazolamide & Carbonic anhydrase [87] & No effect [49] & No effect \\
\hline Torsemide & NKCC2 $[82]$ & - & No effect \\
\hline Triamterene & $\mathrm{ENaC}[82]$ & No effect [49] & No effect \\
\hline Spironolactone & Aldosterone antagonist $[82,85]$ & No effect [49] & No effect \\
\hline \multicolumn{4}{|c|}{ Chloride channels and anion transport blockers } \\
\hline CFTR-inhibitor 172 & CFTR $[88]$ & No effect [49] & No effect $(1.6 \mu \mathrm{M})$ \\
\hline \multirow[t]{6}{*}{ DIDS } & Anion transport [89-91] & No effect [49] & No effect \\
\hline & & No effect $(0.5 \mathrm{mM})[50]$ & $48 \%$ inhibition $(1 \mathrm{mM})$ \\
\hline & & No effect $(0.5 \mathrm{mM})[44]$ & \\
\hline & & $88 \%$ inhibition $(0.5 \mathrm{mM})[51]$ & \\
\hline & & Full inhibition (0.5 mM) [52] & \\
\hline & & $62 \%$ inhibition $(1 \mathrm{mM})[47]$ & \\
\hline DNDS & Anion transport [92] & - & No effect \\
\hline \multirow[t]{2}{*}{ NPPB } & Chloride channels $[75,90]$ & No effect [49] & $33 \%$ inhibition \\
\hline & & $59 \%$ inhibition $[44]$ & \\
\hline \multirow[t]{2}{*}{ Probenecid } & OAT1 [93] & No effect [49] & No effect \\
\hline & & $37 \%$ inhibition $(1 \mathrm{mM})[47]$ & No effect $(1 \mathrm{mM})$ \\
\hline \multicolumn{4}{|c|}{ Previously identified inhibitors of SLC26A3 (DRA) } \\
\hline Glybenclamide & KCNJ1 $[94]$ & No effect [49] & No effect \\
\hline \multirow[t]{2}{*}{ Hydroxycinnamate } & & No effect [49] & No effect \\
\hline & & No effect (1 mM) [50] & \\
\hline \multirow[t]{2}{*}{ Niflumic acid } & COX, PLA2 $[91,95]$ & Inhibition (0.25 mM) [25] & $64 \%$ inhibition \\
\hline & & Inhibition $[44,49]$ & \\
\hline Tenidap & COX [64], LOX [65] (?) & $49 \%$ inhibition $[50]$ & $30 \%$ inhibition \\
\hline
\end{tabular}

Italy. The plasmid encoding for the enhanced yellow fluorescent protein (EYFP) H148Q;I152L (an EYFP mutant with substantially improved sensitivity for iodide [32]) was obtained by site-directed mutagenesis of the pEYFPN1 vector (Clontech) and is heretofore referred to as pEYFP H148Q;1152L N1. All plasmid inserts were sequenced prior to use in experiments (Microsynth AG, Switzerland). 


\section{Cellular Physiology Cell Physiol Biochem 2016;38:1984-1998 \\ and Biochemistry Published online: May 09, $2016 \quad$\begin{tabular}{l|l} 
DOI: 10.1159/000445559 & $\begin{array}{l}\text { (c) } 2016 \text { The Author(s). Published by S. Karger AG, Basel } \\
\text { www.karger.com/cpb }\end{array}$
\end{tabular} \\ Bernardinelli et al.: Effect of Known Inhibitors of Ion Transport on Pendrin}

Cell culture and transient transfection

Human embryonic kidney (HEK) 293 Phoenix [33] cells were cultured in Minimum Essential Eagle Medium (Sigma-Aldrich, Austria) supplemented with 10\% fetal bovine serum (Lonza), 2 mM L-glutamine, $100 \mathrm{U} / \mathrm{ml}$ penicillin, $100 \mu \mathrm{g} / \mathrm{ml}$ streptomycin and $1 \mathrm{mM}$ pyruvic acid (sodium salt). The cells were maintained at $37^{\circ} \mathrm{C}, 5 \% \mathrm{CO}_{2}, 95 \%$ air and $100 \%$ humidity. Subcultures were routinely established every second to third day by seeding the cells into $100 \mathrm{~mm}$ diameter Petri dishes following trypsin/ethylenediaminetetraacetic acid (EDTA) treatment.

For functional tests, cells were seeded into black 96-multiwells, grown overnight and transfected with a total amount of $0.2 \mu \mathrm{g} /$ well of plasmid DNA. For western blots, cells were seeded into 6-well plates, grown overnight and transfected with a total amount of $2 \mu \mathrm{g} /$ well of plasmid DNA. The calcium phosphate coprecipitation method was used for transient transfection into cells.

\section{Western blot}

Cells were transiently transfected with the pTARGET plasmid bearing the cDNA of pendrin or with an empty pTARGET vector (control). 72 hours after transfection cells were collected and centrifuged at $216 \mathrm{x} \mathrm{g}$ for 15 minutes at $4^{\circ} \mathrm{C}$. The extraction of the total membrane protein fraction, including both plasma membrane proteins and membrane proteins from cellular organelles, was obtained with the Plasma Membrane Extraction Kit (MBL, USA), according to the manufacturer's instructions. Total cellular membranes proteins were solubilized with $100 \mathrm{mM}$ dithiothreitol and $8 \%$ sodium dodecyl sulphate (SDS) and boiled for 5 minutes before loading on a $7.5 \%$ polyacrylamide gel. Separated proteins were transferred on polyvinylidene difluoride membranes (Immunoblot PVDF Membranes, BIO-RAD, Germany) by applying a constant voltage $(75 \mathrm{~V})$ for 2 hours at $4^{\circ} \mathrm{C}$. The membranes were blocked for 1 hour at room temperature in 5\% nonfat dry milk in Tris-buffered saline and $0.1 \%$ Tween 20 (TBST), cut horizontally in two parts and incubated overnight at $4{ }^{\circ} \mathrm{C}$ with the primary antibodies (rabbit anti-pendrin, polyclonal, raised against amino acids 586-780 of human pendrin, sc-50346, Santa Cruz Biotechnology, 1:500, or rabbit anticalreticulin, ab4, Abcam, 1:1,000) in 3\% nonfat dry milk in phosphate buffered saline (PBS). Membranes were successively washed thrice in TBST, incubated for 1 hour at room temperature with infrared dyeconjugated secondary antibodies (goat anti-rabbit IRDye 800CW conjugated, LI-COR, USA, 1:20,000 in $3 \%$ nonfat dry milk in PBS) and washed thrice in TBST. Detection of the signal of immunocomplexes was obtained with the ODYSSEY infrared imaging system (LI-COR). Blot images were densitometrically analyzed with ImageJ 1.46r software.

\section{Pendrin functional test}

For testing the function of pendrin in the presence of test compounds and the respective vehicles, the influx of iodide was measured in pendrin-overexpressing and control cells. Cells were co-transfected with $0.1 \mu \mathrm{g}$ of pEYFP H148Q;I152L N1 plasmid and $0.1 \mu \mathrm{g}$ of pTARGET plasmid bearing the CDNA of pendrin. Control cells were co-transfected with pEYFP H148Q;I152L N1 and the empty pTARGET vectors. The functional test was performed 48 hours after transient transfection as already described [34-37], with adaptations allowing for the use of a multiplate reader [38-41]. As high transfection efficiency is an essential prerequisite, HEK 293 Phoenix cells, in which transfection efficiencies of $\sim 90 \%$ are obtained, are particularly suitable for this approach. In short, cells were washed from the culture medium and bathed in $70 \mu \mathrm{l}$ of high chloride solution (in mM: $\mathrm{KCl}$ 2, $\mathrm{NaCl} 135, \mathrm{CaCl}_{2} 1, \mathrm{MgCl}_{2}$ 1, D-glucose 10, 4-(2-hydroxyethyl)-1piperazineethane sulfonic acid (HEPES) $20,308 \mathrm{mOsm} / \mathrm{KgH}_{2} \mathrm{O}$ with mannitol, $\mathrm{pH} 7.4$ ) containing $0.3 \mathrm{mM}$ of the test compound or the respective vehicle. After measuring the fluorescence intensity (1 measurement/ sec for $3 \mathrm{sec}$ ), $140 \mu \mathrm{l}$ of high iodide solution (in mM: KCl 2, NaI 135, $\mathrm{CaCl}_{2} 1, \mathrm{MgCl}_{2} 1$, D-glucose 10, HEPES $20,308 \mathrm{mOsm} / \mathrm{KgH}_{2} \mathrm{O}$ with mannitol, $\mathrm{pH}$ 7.4) were injected into each well to obtain a final concentration $0.1 \mathrm{mM}$ for the test compound, except where otherwise specified (Table 1). Then, the fluorescence intensity was measured again ( 1 measurement/sec for $16 \mathrm{sec}$ ). Since pendrin can act as a chloride/iodide exchanger [34, 42,43], the presence of iodide in the extracellular medium induces an iodide flux into the cytoplasm of pendrin-expressing cells. Iodide is a much better quencher of EYFP H148Q;I152L fluorescence than chloride; therefore, an increase in intracellular iodide leads to a decrease of EYFP H148Q;1152L fluorescence [32], which reflects pendrin transport efficiency in pendrin-overexpressing cells. Fluorescence variations in control cells (not overexpressing pendrin) reflect the activity of anion channels/transporters endogenously expressed in HEK 293 Phoenix cells. Experiments were performed at room temperature. 


\section{Cellular Physiology Cell Physiol Biochem 2016;38:1984-1998 \begin{tabular}{ll|l} 
DOI: 10.1159/000445559 & $\begin{array}{l}\text { O 2016 The Author(s). Published by S. Karger AG, Basel } \\
\text { www.karger.com/cpb }\end{array}$
\end{tabular} \\ Bernardinelli et al.: Effect of Known Inhibitors of Ion Transport on Pendrin}

Fig. 1. Pendrin expression levels in control and transiently transfected HEK 293 Phoenix cells. (a) representative immunoblotting on total cellular membrane extracts from control and pendrin transfected HEK 293 Phoenix cells. Control cells were transfected with an empty vector. 1, 2 and 3 in the upper panel indicate the non-glycosylated, partially glycosylated and maturely glycosylated forms of pendrin, respectively. The lower panel corresponds to the signal of the housekeeping protein calreticulin. (b) the expression levels of pendrin were quantified by densitometry and normalized to calreticulin. $\mathrm{n}=4,{ }^{* * *}: \mathrm{p}<0.001$, two-tailed, unpaired Student's t test.

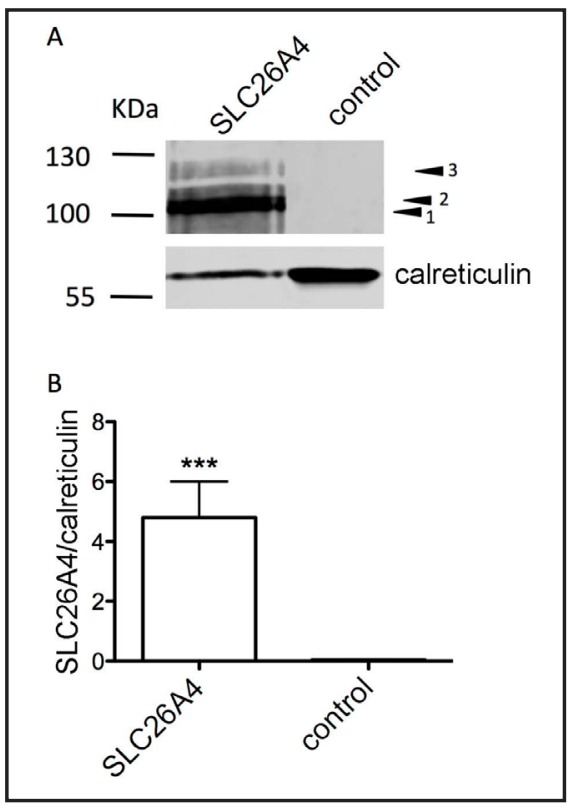

Fluorescence intensity was detected with the VICTOR ${ }^{\mathrm{TM}} \mathrm{X} 3$ Multilabel Plate Reader (Perkin Elmer) equipped with a liquid dispenser and the following filters: excitation: F485 (excitation center wavelength (CWL): $485 \mathrm{~nm}$, bandwidth: $14 \mathrm{~nm}$ ), emission: F535 (emission CWL: $535 \mathrm{~nm}$, bandwidth: $25 \mathrm{~nm}$ ). The background fluorescence measured in cells transfected with $0.2 \mu \mathrm{g}$ of the pTARGET empty vector was subtracted from all other fluorescence measurements of the same 96-well plate. Data were expressed as \% fluorescence variations $(\Delta \mathrm{F} \%)$. The transport activity of pendrin expressing or control cells in the presence of the test compound was statistically compared to the transport activity of pendrin expressing or control cells in the presence of the appropriate vehicle from a same 96-well plate.

\section{Salts and chemicals}

4, 4'-diisothiocyano-2,2'-stilbene-disulfonic acid (DIDS; D3514), 4, 4'-dinitrostilbene-2, 2'-disulfonic acid (DNDS; S347523), 5-nitro-2-[(3-phenylpropyl)amino]benzoic acid (NPPB; N4779), acetazolamide (A6011), amiloride (A7410), bumetanide (B3023), CFTR inhibitor-172 (C2992), chlorothiazide (C4911), eplerenone (E6657), furosemide (F4381), glybenclamide (G0639), hydrochlorothiazide (H4759), hydroflumethiazide (H8760), hydroxycinnamic acid (545287), indapamide (I1887), methazolamide

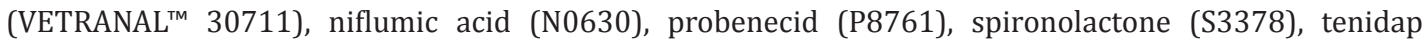
(PZ0196), torsemide (T3202) and triamterene (T4143) were purchased from Sigma-Aldrich (Austria). Stock solutions $(0.1 \mathrm{M})$ were prepared in an appropriate organic solvent and stored at $-20^{\circ} \mathrm{C}$ in the dark. All salts and chemicals used were of pro analysis grade.

\section{Statistical Analysis}

All data were expressed as arithmetic means \pm S.E.M. For statistical analysis, GraphPad Prism software (version 4.00 for Windows, GraphPad Software, San Diego, California, USA) was used. Significant differences between data sets were tested by one way Analysis of Variance (ANOVA) with Bonferroni's multiple comparison ad hoc post-test or unpaired Student's t test, as appropriated. Statistically significant differences between data sets were assumed at $\mathrm{p}<0.05$; (n) corresponds to the number of independent measurements.

\section{Results}

Expression levels of pendrin in total cellular membrane protein extracts of control and pendrin transfected cells were evaluated by western blot (Fig. 1). In control cells, pendrin expression was virtually undetectable, in agreement with previous findings [41, 44]. Following transfection, a significant increase in pendrin protein expression was observed. 


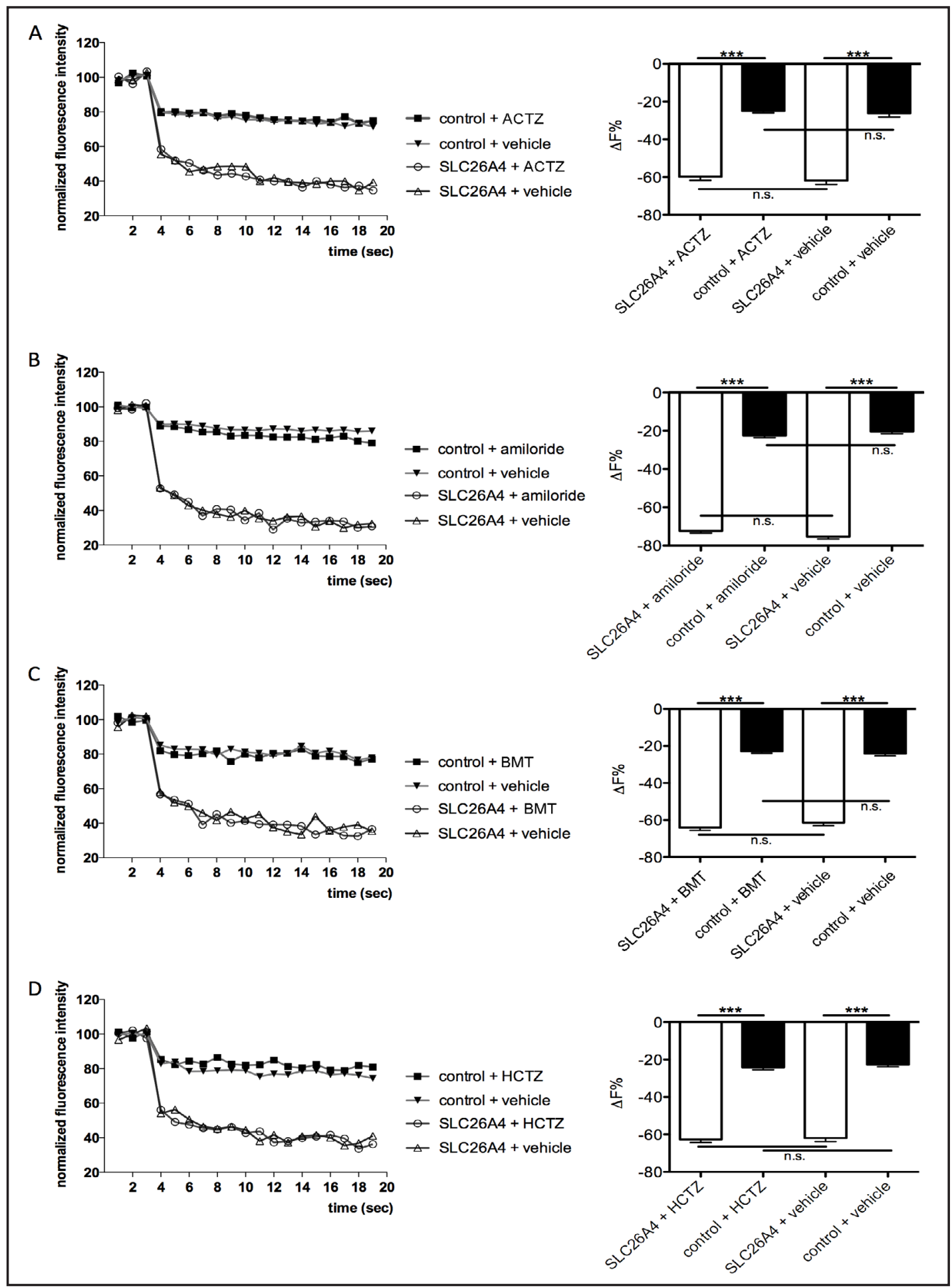

Fig. 2. Pendrin activity is resistant to known diuretics. Representative original recording of the intracellular fluorescence intensity (left) and percentage of fluorescence decrease $(\Delta \mathrm{F} \%$, right) determined over the experimental period (19 sec) in HEK 293 Phoenix cells transfected with pendrin (SLC26A4, white bars) or in control cells (control, black bars) in the presence of $0.1 \mathrm{mM}$ (a) acetazolamide (ACTZ; $n=30$ ), (b) amiloride ( $n=24)$, (c) bumetanide (BMT; $n=24)$, or (d) hydrochlorothiazide (HCTZ; $n=24$ ) or the corresponding vehicle. Data were collected from 4-5 independent experiments. ***: $\mathrm{p}<0.001$, n.s.: not statistically significant, one-way Anova with Bonferroni's multiple comparison post-test. 


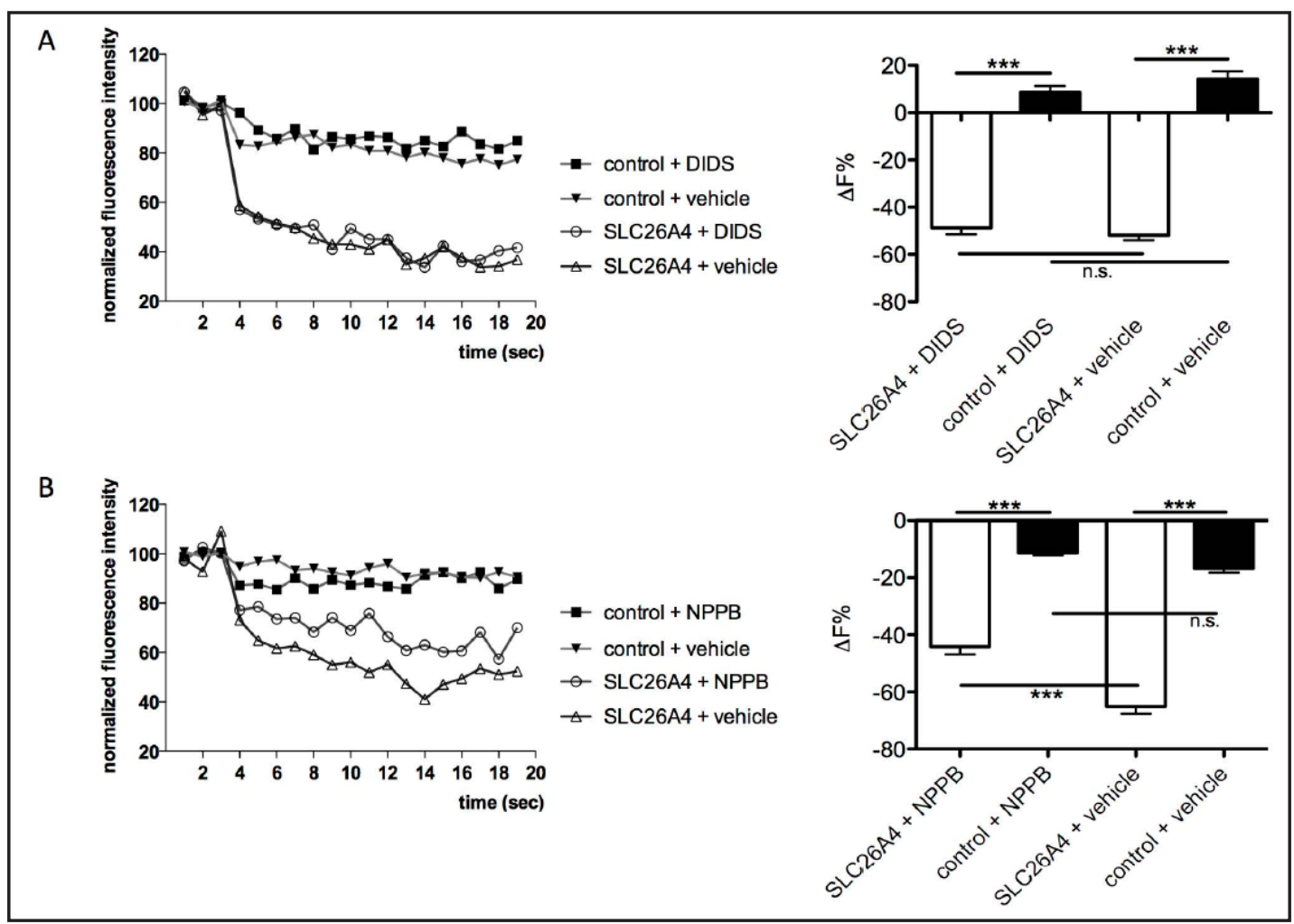

Fig. 3. Pendrin activity is resistant to DIDS and sensitive to NPPB. Representative original recording of the intracellular fluorescence intensity (left) and percentage of fluorescence decrease $(\Delta \mathrm{F} \%$, right) determined over the experimental period (19 sec) in HEK 293 Phoenix cells transfected with pendrin (SLC26A4, white bars) or in control cells (control, black bars) in the presence of $0.1 \mathrm{mM}$ (a) DIDS ( $=48$ ) or (b) NPPB $(n=24)$, or the corresponding vehicle. Data were collected from 8 and 4 independent experiments for a and b, respectively. ${ }^{* * *}: \mathrm{p}<0.001$, n.s.: not statistically significant, one-way Anova with Bonferroni's multiple comparison post-test.

Bands between 100 and $130 \mathrm{kDa}$ represent the non-glycosylated, partially glycosylated and maturely glycosylated forms of pendrin and correspond to that described in previous reports $[45,46]$.

The compounds tested on pendrin activity (divided in three categories as follows: established diuretics and hypertensive agents, blockers of anion transport and previously identified inhibitors of solute carrier family 26, member A3/down-regulated in adenoma, SLC26A3/DRA) are represented in Table 1. The outcome of the functional test in the presence of compounds representative of each of the aforementioned categories is represented in Fig. 2-4. Addition of iodide to the extracellular solution invariably led to a marked decrease in the fluorescence of the iodide sensor (EYFP H148Q;1152L) in vehicle-exposed pendrin transfected cells (SLC26A4 + vehicle, Fig. 2-4). This effect was significantly different $(\mathrm{p}<0.001)$ from that measured in cells transfected with the iodide sensor alone and exposed to the same vehicle (control + vehicle, Fig. 2-4), thereby confirming that pendrin does transport iodide $[47,48]$, most likely acts as a $\mathrm{Cl}^{-} / \mathrm{I}^{-}$anion exchanger in this system $[34]$ and that the vehicles used in the present study do not significantly interfere with pendrin activity. The fluorescence variations detected in control cells exposed to a given test compound did not differ significantly from those measured in control cells exposed to the corresponding vehicle, indicating that endogenous anion transport was not affected. The only exception to this was the use of $1 \mathrm{mM}$ probenecid (see below). 


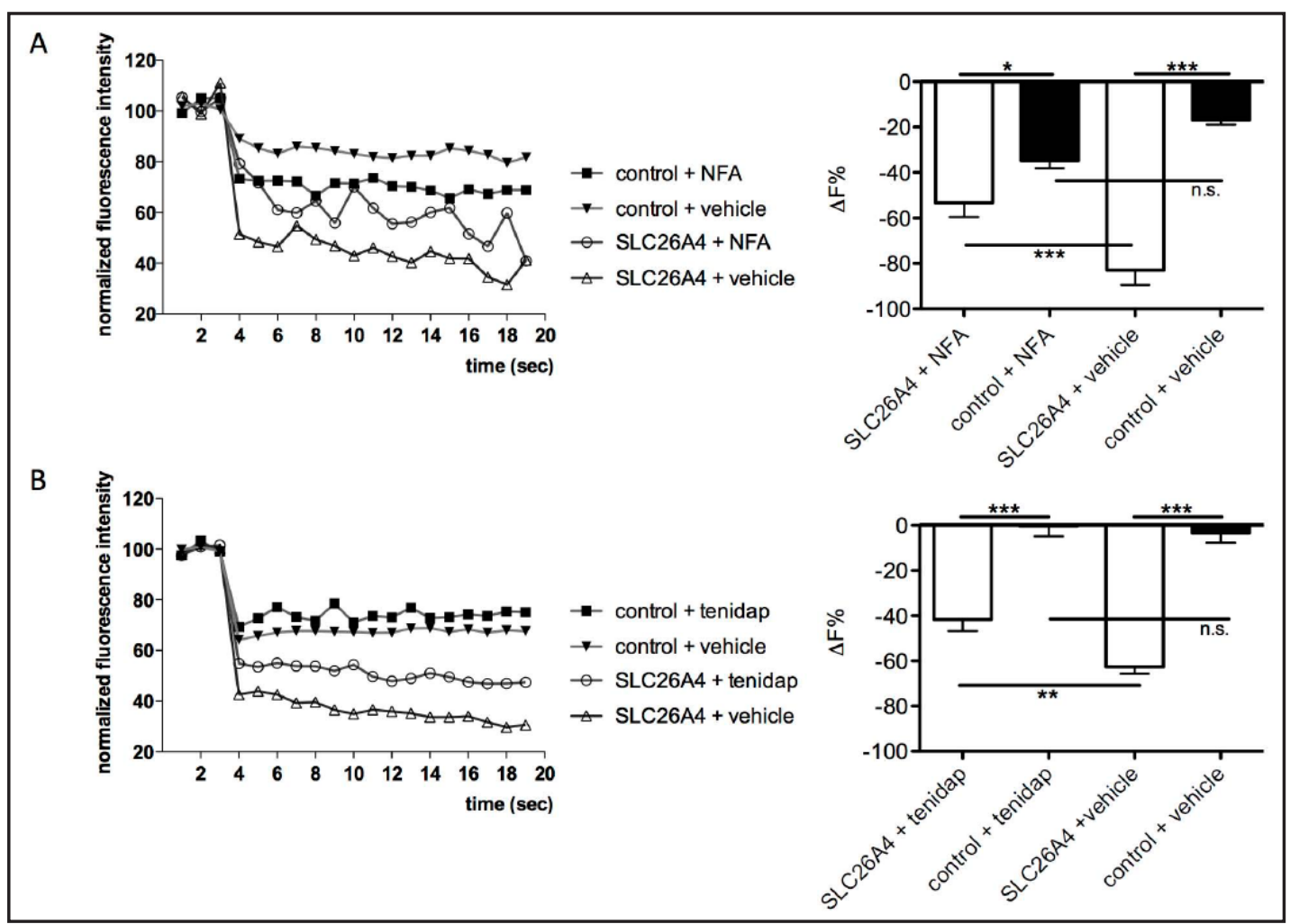

Fig. 4. Pendrin activity is sensitive to niflumic acid and tenidap. Representative original recording of the intracellular fluorescence intensity (left) and percentage of fluorescence decrease $(\Delta \mathrm{F} \%$, right) determined over the experimental period (19 sec) in HEK 293 Phoenix cells transfected with pendrin (SLC26A4, white bars) or in control cells (control, black bars) in the presence of $0.1 \mathrm{mM}$ (a) niflumic acid (NFA; $\mathrm{n}=12$ ) or (b) tenidap $(\mathrm{n}=48)$, or the corresponding vehicle. Data were collected from 2 and 8 independent experiments for a and b, respectively. ${ }^{*}$ : $\mathrm{p}<0.05,{ }^{* *}$ : $\mathrm{p}<0.01,{ }^{* * *}$ : $\mathrm{p}<0.001$, n.s.: not statistically significant, one-way Anova with Bonferroni's multiple comparison post-test.

Pendrin activity is not affected by thiazides and commonly used diuretics

Thirteen diuretics were selected among classes with established targets in distinct segments of the nephron, specifically (i) the carbonic anhydrase in the proximal tubule, (ii) the $\mathrm{Na}^{+} / \mathrm{K}^{+} / 2 \mathrm{Cl}^{-}$contransporter (NKCC) in the thick ascending limb, (iii) NCC in the distal convolute tubule, (iv) ENaC in the CCD and CNT and (v) the aldosterone pathway in the distal nephron (Table 1). None of them significantly altered pendrin-dependent iodide influx (Fig. 2 and Table 1) when used at a concentration of $0.1 \mathrm{mM}$. Increasing the concentration of furosemide to $1 \mathrm{mM}$ significantly hampered $(\sim 39 \%)$ pendrin activity $(\mathrm{p}<0.001, \mathrm{n}=42)$.

Pendrin activity is resistant to DIDS but affected by NPPB

Five established inhibitors of chloride channels and anion exchangers were tested on pendrin activity (Table 1). When used at a concentration of $0.1 \mathrm{mM}$, only NPPB lead to a significant (33\%) inhibition of pendrin-dependent iodide influx (Fig. 3b and Table 1). Increasing the concentration of DIDS to $1 \mathrm{mM}$ significantly blocked ( 48\%) pendrin activity $(\mathrm{p}<0.001, \mathrm{n}=42)$, while $1 \mathrm{mM}$ probenecid altered the anion transport in control cells $(\mathrm{p}<$ $0.001, \mathrm{n}=42$ ) with no effect on pendrin-dependent iodide influx. However, $1 \mathrm{mM}$ DIDS also significantly inhibited $(\sim 23 \%$; $<<0.001, \mathrm{n}=10)$ voltage-dependent, potassium-selective channels endogenously expressed in HEK 293 Phoenix cells (data not shown).

Pendrin activity is affected by niflumic acid and tenidap

Four compounds previously reported to inhibit the activity of SLC26A3/DRA were tested (Table 1) on pendrin activity. Of them, niflumic acid and tenidap led to a significant 


\section{Cellular Physiology Cell Physiol Biochem 2016;38:1984-1998 \\ and Biochemistry Published online: May 09, $2016 \quad$\begin{tabular}{l|l} 
DOI: 10.1159/000445559 2016 The Author(s). Published by S. Karger AG, Basel \\
www.karger.com/cpb
\end{tabular} \\ Bernardinelli et al.: Effect of Known Inhibitors of Ion Transport on Pendrin}

(64 and 30\%, respectively) inhibition of pendrin-dependent iodide influx (Fig. $4 \mathrm{a}$ and b and Table 1).

\section{Discussion}

Six known inhibitors of ion transport (DIDS, furosemide, niflumic acid, NPPB, probenecid and tenidap) were previously reported as capable of inhibiting pendrin activity, but some (DIDS, furosemide, NPPB, probenecid) led to discordant results and were therefore re-assayed in the present study.

Incongruous effects of some compounds on pendrin transport activity may arise from differences in the concentration used in each individual study. The concentration of most of the compounds tested in the present work $(0.1 \mathrm{mM})$ was based on previous studies [44, 49, 50]. Although this exceeds the $\mathrm{IC}_{50}$ for the respective conventional targets (Table 1 ), it was chosen with the aim of unequivocally excluding ineffective substances. In an initial report, relatively high concentrations ( $1 \mathrm{mM}$ ) of DIDS lead to a $62 \%$ inhibition of radiolabelled chloride uptake in pendrin-expressing Xenopus oocytes [47]. In later studies, DIDS was found either to almost completely inhibit $(0.5 \mathrm{mM})$ pendrin activity $[51,52]$ or to be ineffective (0.1-0.5 mM) [44, 49, 50]. In the present study, $0.1 \mathrm{mM}$ DIDS and the closely related DNDS did not block pendrin activity (Table 1 and Fig. 3a), in agreement with historical observations on $\beta$-intercalated cell dependent $\mathrm{HCO}_{3}{ }^{-}$secretion, that was found to be DIDS insensitive [53, 54]. Increasing the DIDS concentration to $1 \mathrm{mM}$ led to a $48 \%$ inhibition of pendrin activity (Table 1), but also significantly affected potassium-selective currents, and is therefore considered to be largely unspecific.

Similarly to DIDS, furosemide and probenecid $(1 \mathrm{mM})$ were initially reported to inhibit radiolabelled chloride uptake in pendrin-expressing Xenopus oocytes by $59 \%$ and $37 \%$, respectively [47], and then later showed to be ineffective [49]. In the present study, neither $0.1 \mathrm{mM}$ furosemide nor probenecid inhibited pendrin-driven iodide influx (Table 1). Increasing the furosemide concentration to $1 \mathrm{mM}$ led to a $39 \%$ inhibition of pendrin activity, while $1 \mathrm{mM}$ probenecid affected the endogenous anion transport in the cell utilized for the functional tests, without affecting pendrin-dependent iodide influx (Table 1).

In a former study, we showed that $0.1 \mathrm{mM}$ NPPB, a known inhibitor of anion channels that is not expected to inhibit anion exchangers, significantly blocked pendrin-induced chloride uptake [44], a finding that could not be reproduced on SCN- transport [49]. Here we found that $0.1 \mathrm{mM}$ NPPB leads to a $\sim 33 \%$ inhibition of pendrin-driven iodide influx (Table 1 and Fig. 3b).

Among the SLC26 family members, SLC26A3/DRA is the closest paralog of pendrin with the two proteins showing $44 \%$ identity and $60 \%$ similarity [55]. Therefore, we verified if some established inhibitors of SLC26A3/DRA (glybenclamide, hydroxycinnamate, niflumic acid and tenidap, Table 1) were also effective against pendrin activity. Of those, $0.1 \mathrm{mM}$ glybenclamide was reported to significantly affect SLC26A3/DRA activity [56], while hydroxycinnamate was relatively weaker [57]. However, in the present study, neither glybenclamide nor hydroxycinnamate inhibited pendrin activity (Table 1), in agreement with other reported observations $[49,50]$.

The anti-inflammatory drug niflumic acid is known to exert its action via cyclooxygenase inhibition [58], but it is also involved in the modulation of chloride channels, such as ClC$\mathrm{Ka}$ and $\mathrm{ClC}-\mathrm{Kb}$ [59], and was shown to efficiently block SLC26A3/DRA activity [57, 60]. Niflumic acid led to a $\sim 64 \%$ inhibition of pendrin-driven iodide influx (Table 1 and Fig. 4 a), therefore confirming our former findings obtained with radiolabelled chloride uptake [44]. Noteworthy, screening a library of 2,000 compounds later confirmed that niflumic acid decreased pendrin-dependent $\mathrm{SCN}^{-}$transport [49]. Niflumic acid also inhibited pendrin-induced iodide uptake and Mucin 5AC production in stably transfected NCI H292 cells [25]. As previously mentioned, in the respiratory epithelium, pendrin expression is enhanced upon stimulation of the IL-4/13 pathway [23] and exacerbates the pathological 


\section{Cellular Physiology Cell Physiol Biochem 2016;38:1984-1998 \\ and Biochemistry Published online: May 09, $2016 \quad \begin{aligned} & \text { DOI: 10.1159/00044559 } 2016 \text { The Author(s). Published by S. Karger AG, Basel } \\ & \text { www.karger.com/cpb }\end{aligned}$ \\ Bernardinelli et al.: Effect of Known Inhibitors of Ion Transport on Pendrin}

manifestations of respiratory distresses [20]. Pendrin sensitivity to niflumic acid is in agreement with findings showing that this drug could ameliorate IL-13-induced asthma features such as airway hyperresponsiveness, goblet cell hyperplasia and degranulation and eosinophil accumulation $[61,62]$, although inhibition of the calcium-activated chloride channel/chloride channel regulator mCLCA3 (mouse homolog of hCLCA1) was postulated to be the underlying mechanism in those studies.

Tenidap is an anti-rheumatic, anti-inflammatory drug effective against rheumatic arthritis [63]. Its action is related to the inhibition of cyclooxygenases 1 and 2 [64], as well as lipooxygenase 5 [65], but it is also known to modulate a number of membrane transporters and channels, including the rat kidney $\mathrm{Na}^{+} / \mathrm{HCO}_{3}{ }^{-}$cotransporter (rkNBC) [66] and the inwardly rectifying $\mathrm{K}^{+}$channel Kir2.3 [67]. Tenidap was shown to efficiently block SLC26A3/ DRA activity in Xenopus oocytes [57] and HEK 293 cells [56], as well as pendrin activity in Xenopus oocytes [50]. Here we confirm that tenidap also blocks pendrin activity following expression in human kidney cells (Table 1 and Fig. 4b).

Pendrin activity was found to be resistant to thiazides (Table 1). This finding is particularly relevant when considering that pendrin expression is upregulated in a setting of NCC gene ablation $[16,68]$ or impeded NCC activation [69], conditions that can be regarded as analogous to the state resulting from chronic thiazide treatment. The resistance of pendrin to thiazides is consistent with the development of thiazide diuretics resistance following prolonged therapy [70].

As previously mentioned, the functional test utilized here evaluates the $\mathrm{Cl}^{-} / \mathrm{I}^{-}$exchange activity of pendrin [34-37]. The $\mathrm{Cl}^{-} / \mathrm{I}^{-}$exchange activity, in general, reflects the $\mathrm{Cl}^{-} / \mathrm{HCO}_{3}{ }^{-} / \mathrm{OH}^{-}$ exchange activity [71]; when differences between the $\mathrm{Cl}^{-} / \mathrm{I}^{-}$and $\mathrm{Cl}^{-} / \mathrm{HCO}_{3}$ exchange efficiency were observed, they were considered to be "moderate", and unlikely of pathophysiological relevance [72]. In addition, in the kidney, pendrin plays a role in $\mathrm{I}^{-}$absorption, thus contributing to $\mathrm{I}^{-}$balance $[73,74]$. Therefore, the $\mathrm{Cl}^{-} / \mathrm{I}^{-}$exchange activity can be used as a reliable tool to measure pendrin transport efficiency. In addition, inhibitors of anion transport can lead to intracellular acidification [75], therefore indirectly affecting pendrin $\mathrm{Cl}^{-} / \mathrm{HCO}_{3}{ }^{-}$ activity by limiting the availability of intracellular $\mathrm{HCO}_{3}{ }^{-}$. The $\mathrm{Cl}^{-} / \mathrm{I}^{-}$exchange transport mode does not affect the intracellular $\mathrm{pH}$ and therefore does not rely on intracellular $\mathrm{HCO}_{3}{ }^{-}$[34]. Therefore, measuring the $\mathrm{Cl}^{-} / \mathrm{I}^{-}$exchange is a suitable approach for testing pendrin activity in the presence of possible decreases in intracellular $\mathrm{pH}$. Moreover, it should be considered that intracellular $\mathrm{pH}$ variations can intrinsically modify the transport kinetics of pendrin, independently of transmembrane concentration gradients, with increased activity at low intracellular $\mathrm{pH}$ [52]. This could have lead to underestimates of the inhibition percentages reported in Table 1.

As previously mentioned, fluorescence \% variations measured in control cells (not overexpressing pendrin) exposed to the tested substances (with the only exception of 1 $\mathrm{mM}$ probenecid) did not significantly differ from those measured in control cells exposed to the respective vehicles; therefore, an effect of NPPB, tenidap and niflumic acid on anion channels/transporters endogenously expressed in HEK 293 Phoenix cells can be excluded.

Theoretically, the inhibitory effect of NPPB, tenidap or niflumic acid observed in the present study may reflect an inhibition of an iodide influx through endogenous chloride channels (such as $\mathrm{ClC} 2$ [76]) that may be activated following pendrin overexpression. This effect would not be apparent in control cells that do not overexpress pendrin. However, previous studies revealed that pendrin overexpression does not activate chloride currents [77]. Therefore, an effect of the aforementioned compounds on endogenously expressed ion channels seems unlikely.

To conclude, we confirmed that human pendrin activity in human kidney cells was inhibited by the anti-inflammatory drug niflumic acid, the anti-rheumatic drug tenidap and the anion channel inhibitor NPPB. Further studies are warranted to verify if niflumic acid (a drug currently in use in clinical practice) and tenidap (a drug that was used in clinical trials $[78,79]$ ) could represent useful adjuncts in the treatment of respiratory distresses and/or hypertensive states. 


\section{Cellular Physiology Cell Physiol Biochem 2016;38:1984-1998

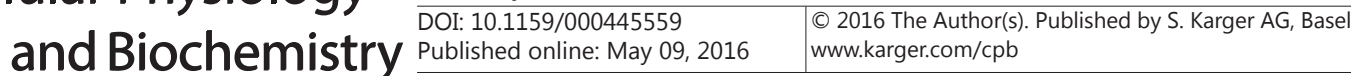 \\ Bernardinelli et al.: Effect of Known Inhibitors of Ion Transport on Pendrin}

\section{Acknowledgments}

We sincerely thank Elisabeth Mooslechner for her expert secretarial assistance.

\section{Disclosure Statement}

The authors have no conflict of interests to declare.

\section{References}

1 Everett LA, Glaser B, Beck JC, Idol JR, Buchs A, Heyman M, Adawi F, Hazani E, Nassir E, Baxevanis AD, Sheffield VC, Green ED: Pendred syndrome is caused by mutations in a putative sulphate transporter gene (PDS). Nat Genet 1997;17:411-422.

2 Li XC, Everett LA, Lalwani AK, Desmukh D, Friedman TB, Green ED, Wilcox ER: A mutation in PDS causes non-syndromic recessive deafness. Nat Genet 1998;18:215-217.

3 Royaux IE, Wall SM, Karniski LP, Everett LA, Suzuki K, Knepper MA, Green ED: Pendrin, encoded by the Pendred syndrome gene, resides in the apical region of renal intercalated cells and mediates bicarbonate secretion. Proc Natl Acad Sci U S A 2001;98:4221-4226.

4 Kim YH, Kwon TH, Frische S, Kim J, Tisher CC, Madsen KM, Nielsen S: Immunocytochemical localization of pendrin in intercalated cell subtypes in rat and mouse kidney. Am J Physiol Renal Physiol 2002;283:F744-F754.

5 Wall SM, Hassell KA, Royaux IE, Green ED, Chang JY, Shipley GL, Verlander JW: Localization of pendrin in mouse kidney. Am J Physiol Renal Physiol 2003;284:F229-F241.

6 Amlal H, Petrovic S, Xu J, Wang Z, Sun X, Barone S, Soleimani M: Deletion of the anion exchanger Slc26a4 (pendrin) decreases apical $\mathrm{Cl}^{-} / \mathrm{HCO}_{3}{ }^{-}$exchanger activity and impairs bicarbonate secretion in kidney collecting duct. Am J Physiol Cell Physiol 2010;299:C33-C41.

7 Wall SM, Kim YH, Stanley L, Glapion DM, Everett LA, Green ED, Verlander JW: NaCl restriction upregulates renal Slc26a4 through subcellular redistribution: role in $\mathrm{Cl}^{-}$conservation. Hypertension 2004;44:982-987.

8 Verlander JW, Kim YH, Shin W, Pham TD, Hassell KA, Beierwaltes WH, Green ED, Everett L, Matthews SW, Wall SM: Dietary $\mathrm{Cl}(-)$ restriction upregulates pendrin expression within the apical plasma membrane of type B intercalated cells. Am J Physiol Renal Physiol 2006;291:F833-F839.

9 Wall SM: The Role of Pendrin in Blood Pressure Regulation. Am J Physiol Renal Physiol 2015;2015 Nov 4:ajprenal.00400.2015.

10 Wall SM, Lazo-Fernandez Y: The role of pendrin in renal physiology. Annu Rev Physiol 2015;77:363-378.

11 Verlander JW, Hassell KA, Royaux IE, Glapion DM, Wang ME, Everett LA, Green ED, Wall SM: Deoxycorticosterone upregulates PDS (Slc26a4) in mouse kidney: role of pendrin in mineralocorticoidinduced hypertension. Hypertension 2003;42:356-362.

12 Kim YH, Pech V, Spencer KB, Beierwaltes WH, Everett LA, Green ED, Shin W, Verlander JW, Sutliff RL, Wall SM: Reduced ENaC protein abundance contributes to the lower blood pressure observed in pendrin-null mice. Am J Physiol Renal Physiol 2007;293:F1314-F1324.

13 Pech V, Wall SM, Nanami M, Bao HF, Kim YH, Lazo-Fernandez Y, Yue Q, Pham TD, Eaton DC, Verlander JW: Pendrin gene ablation alters ENaC subcellular distribution and open probability. Am J Physiol Renal Physiol 2015;309:F154-F163.

14 Eladari D, Chambrey R, Picard N, Hadchouel J: Electroneutral absorption of $\mathrm{NaCl}$ by the aldosteronesensitive distal nephron: implication for normal electrolytes homeostasis and blood pressure regulation. Cell Mol Life Sci 2014;71:2879-2895.

15 Jacques T, Picard N, Miller RL, Riemondy KA, Houillier P, Sohet F, Ramakrishnan SK, Busst CJ, Jayat M, Corniere N, Hassan H, Aronson PS, Hennings JC, Hubner CA, Nelson RD, Chambrey R, Eladari D: Overexpression of pendrin in intercalated cells produces chloride-sensitive hypertension. J Am Soc Nephrol 2013;24:1104-1113.

16 Soleimani M, Barone S, Xu J, Shull GE, Siddiqui F, Zahedi K, Amlal H: Double knockout of pendrin and $\mathrm{Na}-\mathrm{Cl}$ cotransporter (NCC) causes severe salt wasting, volume depletion, and renal failure. Proc Natl Acad Sci USA 2012;109:13368-13373. 


\section{Cellular Physiology Cell Physiol Biochem 2016;38:1984-1998 \begin{tabular}{ll|l} 
DOI: 10.1159/000445559 & $\begin{array}{l}\text { O 2016 The Author(s). Published by S. Karger AG, Basel } \\
\text { www.karger.com/cpb }\end{array}$
\end{tabular} \\ Bernardinelli et al.: Effect of Known Inhibitors of Ion Transport on Pendrin}

17 Amlal H, Soleimani M: Pendrin as a novel target for diuretic therapy. Cell Physiol Biochem 2011;28:521526.

18 Soleimani M: A novel target for diuretic therapy. Iran J Kidney Dis 2012;6:419-425.

19 Denton JS, Pao AC, Maduke M: Novel diuretic targets. Am J Physiol Renal Physiol 2013;305:F931-F942.

20 Nofziger C, Dossena S, Suzuki S, Izuhara K, Paulmichl M: Pendrin function in airway epithelia. Cell Physiol Biochem 2011;28:571-578.

21 Sala-Rabanal M, Yurtsever Z, Berry KN, Brett TJ: Novel Roles for Chloride Channels, Exchangers, and Regulators in Chronic Inflammatory Airway Diseases. Mediators Inflamm 2015;2015:497387.

22 Kuperman DA, Lewis CC, Woodruff PG, Rodriguez MW, Yang YH, Dolganov GM, Fahy JV, Erle DJ: Dissecting asthma using focused transgenic modeling and functional genomics. J Allergy Clin Immunol 2005;116:305311.

23 Nofziger C, Vezzoli V, Dossena S, Schonherr T, Studnicka J, Nofziger J, Vanoni S, Stephan S, Silva M, Meyer G, Paulmichl M: STAT6 Links IL-4/IL-13 Stimulation With Pendrin Expression in Asthma and Chronic Obstructive Pulmonary Disease. Clin Pharmacol Ther 2011;90:399-405.

24 Vanoni S, Nofziger C, Dossena S, Soyal SM, Patsch W, Plevani P, Duschl A, Paulmichl M: The human pendrin promoter contains two N4 GAS motifs with different functional relevance. Cell Physiol Biochem 2013;32:238-248.

25 Nakao I, Kanaji S, Ohta S, Matsushita H, Arima K, Yuyama N, Yamaya M, Nakayama K, Kubo H, Watanabe M, Sagara H, Sugiyama K, Tanaka H, Toda S, Hayashi H, Inoue H, Hoshino T, Shiraki A, Inoue M, Suzuki K, Aizawa H, Okinami S, Nagai H, Hasegawa M, Fukuda T, Green ED, Izuhara K: Identification of pendrin as a common mediator for mucus production in bronchial asthma and chronic obstructive pulmonary disease. J Immunol 2008;180:6262-6269.

26 Nakagami Y, Favoreto S Jr, Zhen G, Park SW, Nguyenvu LT, Kuperman DA, Dolganov GM, Huang X, Boushey HA, Avila PC, Erle DJ: The epithelial anion transporter pendrin is induced by allergy and rhinovirus infection, regulates airway surface liquid, and increases airway reactivity and inflammation in an asthma model. J Immunol 2008;181:2203-2210.

27 Yick CY, Zwinderman AH, Kunst PW, Grunberg K, Mauad T, Dijkhuis A, Bel EH, Baas F, Lutter R, Sterk PJ: Transcriptome sequencing (RNA-Seq) of human endobronchial biopsies: asthma versus controls. Eur Respir J 2013;42:662-670.

28 Adams KM, Abraham V, Spielman D, Kolls JK, Rubenstein RC, Conner GE, Cohen NA, Kreindler JL: IL-17A induces Pendrin expression and chloride-bicarbonate exchange in human bronchial epithelial cells. PLoS One 2014;9:e103263.

29 Scanlon KM, Gau Y, Zhu J, Skerry C, Wall SM, Soleimani M, Carbonetti NH: Epithelial anion transporter pendrin contributes to inflammatory lung pathology in mouse models of Bordetella pertussis infection. Infect Immun 2014;82:4212-4221.

30 Sharma AK, Zelikovic I, Alper SL: Molecular dynamics simulations of the STAS domains of rat prestin and human pendrin reveal conformational motions in conserved flexible regions. Cell Physiol Biochem 2014;33:605-620.

31 Haggie PM, Phuan PW, Tan JA, Zlock L, Finkbeiner WE, Verkman AS: Inhibitors of pendrin anion exchange identified in a small molecule screen increase airway surface liquid volume in cystic fibrosis. FASEB J 2016.

32 Galietta LJ, Haggie PM, Verkman AS: Green fluorescent protein-based halide indicators with improved chloride and iodide affinities. FEBS Lett 2001;499:220-224.

33 DiCiommo DP, Duckett A, Burcescu I, Bremner R, Gallie BL: Retinoblastoma protein purification and transduction of retina and retinoblastoma cells using improved alphavirus vectors. Invest Ophthalmol Vis Sci 2004;45:3320-3329.

34 Dossena S, Rodighiero S, Vezzoli V, Bazzini C, Sironi C, Meyer G, Furst J, Ritter M, Garavaglia ML, Fugazzola L, Persani L, Zorowka P, Storelli C, Beck-Peccoz P, Botta G, Paulmichl M: Fast fluorometric method for measuring pendrin (SLC26A4) $\mathrm{Cl}^{-} / \mathrm{I}^{-}$transport activity. Cell Physiol Biochem 2006;18:67-74.

35 Fugazzola L, Cirello V, Dossena S, Rodighiero S, Muzza M, Castorina P, Lalatta F, Ambrosetti U, Beck-Peccoz P, Botta G, Paulmichl M: High phenotypic intrafamilial variability in patients with Pendred syndrome and a novel duplication in the SLC26A4 gene: clinical characterization and functional studies of the mutated SLC26A4 protein. Eur J Endocrinol 2007;157:331-338. 


\section{Cellular Physiology Cell Physiol Biochem 2016;38:1984-1998 and Biochemistry Published online: May 09, $2016 \quad \begin{aligned} & \text { DOI: 10.1159/000445559 } 2016 \text { The Author(s). Published by S. Karger AG, Basel } \\ & \text { www.karger.com/cpb }\end{aligned}$ \\ Bernardinelli et al.: Effect of Known Inhibitors of Ion Transport on Pendrin}

36 Pera A, Dossena S, Rodighiero S, Gandia M, Botta G, Meyer G, Moreno F, Nofziger C, Hernandez-Chico C, Paulmichl M: Functional assessment of allelic variants in the SLC26A4 gene involved in Pendred syndrome and nonsyndromic EVA. Proc Natl Acad Sci USA 2008;105:18608-18613.

37 Dror AA, Politi Y, Shahin H, Lenz DR, Dossena S, Nofziger C, Fuchs H, Hrabe de AM, Paulmichl M, Weiner S, Avraham KB: Calcium oxalate stone formation in the inner ear as a result of an Slc26a4 mutation. J Biol Chem 2010;285:21724-21735.

38 Dossena S, Nofziger C, Brownstein Z, Kanaan M, Avraham KB, Paulmichl M: Functional characterization of pendrin mutations found in the Israeli and Palestinian populations. Cell Physiol Biochem 2011;28:477-484.

39 Dossena S, Bizhanova A, Nofziger C, Bernardinelli E, Ramsauer J, Kopp P, Paulmichl M: Identification of allelic variants of pendrin (SLC26A4) with loss and gain of function. Cell Physiol Biochem 2011;28:467476.

40 Procino G, Milano S, Tamma G, Dossena S, Barbieri C, Nicoletti C, Ranieri M, Di Mise A, Nofziger C, Svelto M, Paulmichl M, Valenti G: Co-regulated pendrin and aquaporin 5 expression and trafficking in type-B intercalated cells under potassium depletion. Cell Physiol Biochem 2013;32:184-199.

41 de Moraes V, Bernardinelli E, Zocal N, Fernandez J, Nofziger C, Castilho AM, Sartorato EL, Paulmichl M, Dossena S: Reduction of cellular expression levels is a common feature of functionally affected pendrin (SLC26A4) protein variants. Mol Med 2016 Jan 4.

42 Yoshida A, Hisatome I, Taniguchi S, Sasaki N, Yamamoto Y, Miake J, Fukui H, Shimizu H, Okamura T, Okura T, Igawa O, Shigemasa C, Green ED, Kohn LD, Suzuki K: Mechanism of iodide/chloride exchange by pendrin. Endocrinology 2004;145:4301-4308.

43 Shcheynikov N, Yang D, Wang Y, Zeng W, Karniski LP, So I, Wall SM, Muallem S: The Slc26a4 transporter functions as an electroneutral $\mathrm{Cl}^{-} / \mathrm{I}^{-} / \mathrm{HCO}_{3}{ }^{-}$exchanger: role of Slc26a4 and Slc26a6 in $\mathrm{I}^{-}$and $\mathrm{HCO}_{3}^{-}$secretion and in regulation of CFTR in the parotid duct. J Physiol 2008;586:3813-3824.

44 Dossena S, Vezzoli V, Cerutti N, Bazzini C, Tosco M, Sironi C, Rodighiero S, Meyer G, Fascio U, Furst J, Ritter M, Fugazzola L, Persani L, Zorowka P, Storelli C, Beck-Peccoz P, Botta G, Paulmichl M: Functional characterization of wild-type and a mutated form of SLC26A4 identified in a patient with Pendred syndrome. Cell Physiol Biochem 2006;17:245-256.

45 Yoon JS, Park HJ, Yoo SY, Namkung W, Jo MJ, Koo SK, Park HY, Lee WS, Kim KH, Lee MG: Heterogeneity in the processing defect of SLC26A4 mutants. J Med Genet 2008;45:411-419.

46 Lee K, Hong TJ, Hahn JS: Roles of 17-AAG-induced molecular chaperones and Rma1 E3 ubiquitin ligase in folding and degradation of Pendrin. FEBS Lett 2012;586:2535-2541.

47 Scott DA, Wang R, Kreman TM, Sheffield VC, Karniski LP: The Pendred syndrome gene encodes a chlorideiodide transport protein. Nat Genet 1999;21:440-443.

48 Gillam MP, Sidhaye AR, Lee EJ, Rutishauser J, Stephan CW, Kopp P: Functional characterization of pendrin in a polarized cell system. Evidence for pendrin-mediated apical iodide efflux. J Biol Chem 2004;279:1300413010.

49 Pedemonte N, Caci E, Sondo E, Caputo A, Rhoden K, Pfeffer U, Di CM, Bandettini R, Ravazzolo R, ZegarraMoran O, Galietta LJ: Thiocyanate transport in resting and IL-4-stimulated human bronchial epithelial cells: role of pendrin and anion channels. J Immunol 2007;178:5144-5153.

50 Reimold FR, Heneghan JF, Steward AK, Zelikovic I, Vandorpe DH, Shmukler BE, Alper SL: Pendrin function and regulation in Xenopus oocytes. Cell Physiol Biochem 2011;28:435-450.

51 Soleimani M, Greeley T, Petrovic S, Wang Z, Amlal H, Kopp P, Burnham CE: Pendrin: an apical Cl- $/ \mathrm{OH}^{-} / \mathrm{HCO}_{3}$ exchanger in the kidney cortex. Am J Physiol Renal Physiol 2001;280:F356-F364.

52 Azroyan A, Laghmani K, Crambert G, Mordasini D, Doucet A, Edwards A: Regulation of pendrin by pH: dependence on glycosylation. Biochem J 2011;434:61-72.

53 Ko SB, Luo X, Hager H, Rojek A, Choi JY, Licht C, Suzuki M, Muallem S, Nielsen S, Ishibashi K: AE4 is a DIDSsensitive $\mathrm{Cl}^{-} / \mathrm{HCO}_{3}^{-}$exchanger in the basolateral membrane of the renal CCD and the SMG duct. Am J Physiol Cell Physiol 2002;283:C1206-C1218.

54 Godinich MJ, Jennings ML: Renal chloride-bicarbonate exchangers. Curr Opin Nephrol Hypertens 1995;4:398-401.

55 Mount DB, Romero MF: The SLC26 gene family of multifunctional anion exchangers. Pflugers Arch 2004;447:710-721. 


\section{Cellular Physiology Cell Physiol Biochem 2016;38:1984-1998 and Biochemistry Published online: May 09, $2016 \quad \begin{aligned} & \text { DOI: 10.1159/000445559 } 2016 \text { The Author(s). Published by S. Karger AG, Basel } \\ & \text { www.karger.com/cpb }\end{aligned}$ \\ Bernardinelli et al.: Effect of Known Inhibitors of Ion Transport on Pendrin}

56 Lamprecht G, Baisch S, Schoenleber E, Gregor M: Transport properties of the human intestinal anion exchanger DRA (down-regulated in adenoma) in transfected HEK293 cells. Pflugers Arch 2005;449:479490.

57 Chernova MN, Jiang L, Shmukler BE, Schweinfest CW, Blanco P, Freedman SD, Stewart AK, Alper SL: Acute regulation of the SLC26A3 congenital chloride diarrhoea anion exchanger (DRA) expressed in Xenopus oocytes. J Physiol 2003;549:3-19.

58 Kim BM, Maeng K, Lee KH, Hong SH: Combined treatment with the Cox-2 inhibitor niflumic acid and PPARgamma ligand ciglitazone induces ER stress/caspase-8-mediated apoptosis in human lung cancer cells. Cancer Lett 2011;300:134-144.

59 Picollo A, Liantonio A, Babini E, Camerino DC, Pusch M: Mechanism of interaction of niflumic acid with heterologously expressed kidney CLC-K chloride channels. J Membr Biol 2007;216:73-82.

60 Musch MW, Arvans DL, Wu GD, Chang EB: Functional coupling of the downregulated in adenoma $\mathrm{Cl}^{-} / \mathrm{base}$ exchanger DRA and the apical $\mathrm{Na}^{+} / \mathrm{H}^{+}$exchangers NHE2 and NHE3. Am J Physiol Gastrointest Liver Physiol 2009;296:G202-G210.

61 Nakano T, Inoue H, Fukuyama S, Matsumoto K, Matsumura M, Tsuda M, Matsumoto T, Aizawa H, Nakanishi Y: Niflumic acid suppresses interleukin-13-induced asthma phenotypes. Am J Respir Crit Care Med 2006;173:1216-1221.

62 Kondo M, Nakata J, Arai N, Izumo T, Tagaya E, Takeyama K, Tamaoki J, Nagai A: Niflumic acid inhibits goblet cell degranulation in a guinea pig asthma model. Allergol Int 2012;61:133-142.

63 Breedveld F: Tenidap: a novel cytokine-modulating antirheumatic drug for the treatment of rheumatoid arthritis. Scand J Rheumatol Suppl 1994;100:31-44.

64 Moore PF, Larson DL, Otterness IG, Weissman A, Kadin SB, Sweeney FJ, Eskra JD, Nagahisa A, Sakakibara M, Carty TJ: Tenidap, a structurally novel drug for the treatment of arthritis: antiinflammatory and analgesic properties. Inflamm Res 1996;45:54-61.

65 Blackburn WD Jr, Heck LW, Loose LD, Eskra JD, Carty TJ: Inhibition of 5-lipoxygenase product formation and polymorphonuclear cell degranulation by tenidap sodium in patients with rheumatoid arthritis. Arthritis Rheum 1991;34:204-210.

66 Ducoudret O, Diakov A, Muller-Berger S, Romero MF, Fromter E: The renal $\mathrm{Na}-\mathrm{HCO}_{3}$-cotransporter expressed in Xenopus laevis oocytes: inhibition by tenidap and benzamil and effect of temperature on transport rate and stoichiometry. Pflugers Arch 2001;442:709-717.

67 Liu Y, Liu D, Printzenhoff D, Coghlan MJ, Harris R, Krafte DS: Tenidap, a novel anti-inflammatory agent, is an opener of the inwardly rectifying $\mathrm{K}^{+}$channel hKir2.3. Eur J Pharmacol 2002;435:153-160.

68 Vallet M, Picard N, Loffing-Cueni D, Fysekidis M, Bloch-Faure M, Deschenes G, Breton S, Meneton P, Loffing J, Aronson PS, Chambrey R, Eladari D: Pendrin regulation in mouse kidney primarily is chloride-dependent. J Am Soc Nephrol 2006;17:2153-2163.

69 Grimm PR, Lazo-Fernandez Y, Delpire E, Wall SM, Dorsey SG, Weinman EJ, Coleman R, Wade JB, Welling PA: Integrated compensatory network is activated in the absence of NCC phosphorylation. J Clin Invest 2015;125:2136-2150.

70 Knepper MA: Systems biology of diuretic resistance. J Clin Invest 2015;125:1793-1795.

71 Dossena S, Nofziger C, Tamma G, Bernardinelli E, Vanoni S, Nowak C, Grabmayer E, Kossler S, Stephan S, Patsch W, Paulmichl M: Molecular and functional characterization of human pendrin and its allelic variants. Cell Physiol Biochem 2011;28:451-466.

72 Choi BY, Stewart AK, Madeo AC, Pryor SP, Lenhard S, Kittles R, Eisenman D, Kim HJ, Niparko J, Thomsen J, Arnos KS, Nance WE, King KA, Zalewski CK, Brewer CC, Shawker T, Reynolds JC, Butman JA, Karniski LP, Alper SL, Griffith AJ: Hypo-functional SLC26A4 variants associated with nonsyndromic hearing loss and enlargement of the vestibular aqueduct: genotype-phenotype correlation or coincidental polymorphisms? Hum Mutat 2009;30:599-608.

73 Matsushima Y, Muto S, Taniguchi J, Imai M: Mechanism of iodide transport in the rabbit cortical collecting duct. Clin Exp Nephrol 2006;10:102-110.

74 Kim YH, Pham TD, Zheng W, Hong S, Baylis C, Pech V, Beierwaltes WH, Farley DB, Braverman LE, Verlander JW, Wall SM: Role of pendrin in iodide balance: going with the flow. Am J Physiol Renal Physiol 2009;297:F1069-F1079.

75 Brown CD, Dudley AJ: Chloride channel blockers decrease intracellular pH in cultured renal epithelial LLCPK1 cells. Br J Pharmacol 1996;118:443-444. 


\section{Cellular Physiology Cell Physiol Biochem 2016;38:1984-1998

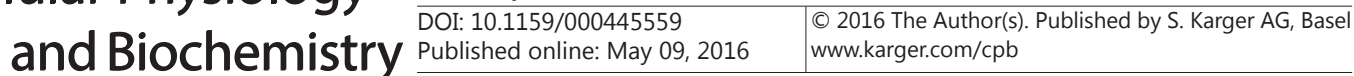 \\ Bernardinelli et al.: Effect of Known Inhibitors of Ion Transport on Pendrin}

76 Domingue JC, Ao M, Sarathy J, George A, Alrefai WA, Nelson DJ, Rao MC: HEK-293 cells expressing the cystic fibrosis transmembrane conductance regulator (CFTR): a model for studying regulation of $\mathrm{Cl}^{-}$transport. Physiol Rep 2014;2:pii:e12158.

77 Dossena S, Maccagni A, Vezzoli V, Bazzini C, Garavaglia ML, Meyer G, Furst J, Ritter M, Fugazzola L, Persani L, Zorowka P, Storelli C, Beck-Peccoz P, Botta G, Paulmichl M: The expression of wild-type pendrin (SLC26A4) in human embryonic kidney (HEK 293 Phoenix) cells leads to the activation of cationic currents. Eur J Endocrinol 2005;153:693-699.

78 Wylie G, Appelboom T, Bolten W, Breedveld FC, Feely J, Leeming MR, Le L, X, Manthorpe R, Marcolongo R, Smolen J: A comparative study of tenidap, a cytokine-modulating anti-rheumatic drug, and diclofenac in rheumatoid arthritis: a 24-week analysis of a 1-year clinical trial. Br J Rheumatol 1995;34:554-563.

79 Ayral X, Mackillop N, Genant HK, Kirkpatrick J, Beaulieu A, Pippingskiold P, Will RK, Alava S, Dougados M: Arthroscopic evaluation of potential structure-modifying drug in osteoarthritis of the knee. A multicenter, randomized, double-blind comparison of tenidap sodium vs piroxicam. Osteoarthritis Cartilage 2003;11:198-207.

80 BELSKY H: Use of a new oral diuretic, diamox, in congestive heart failure. N Engl J Med 1953;249:140-143.

81 McDonald FJ, Snyder PM, McCray PB Jr, Welsh MJ: Cloning, expression, and tissue distribution of a human amiloride-sensitive $\mathrm{Na}^{+}$channel. Am J Physiol 1994;266:L728-L734.

82 Tamargo J, Segura J, Ruilope LM: Diuretics in the treatment of hypertension. Part 2: loop diuretics and potassium-sparing agents. Expert Opin Pharmacother 2014;15:605-621.

83 Monroy A, Plata C, Hebert SC, Gamba G: Characterization of the thiazide-sensitive $\mathrm{Na}^{+}-\mathrm{Cl}^{-}$cotransporter: a new model for ions and diuretics interaction. Am J Physiol Renal Physiol 2000;279:F161-F169.

84 Tamargo J, Segura J, Ruilope LM: Diuretics in the treatment of hypertension. Part 1: thiazide and thiazidelike diuretics. Expert Opin Pharmacother 2014;15:527-547.

85 Frishman WH, Stier CT Jr: Aldosterone and aldosterone antagonism in systemic hypertension. Curr Hypertens Rep 2004;6:195-200.

86 Garay RP, varez-Guerra M, Alda JO, Nazaret C, Soler A, Vargas F: Regulation of renal Na-K-Cl cotransporter NKCC2 by humoral natriuretic factors: relevance in hypertension. Clin Exp Hypertens 1998;20:675-682.

87 Lindskog S: Structure and mechanism of carbonic anhydrase. Pharmacol Ther 1997;74:1-20.

88 Taddei A, Folli C, Zegarra-Moran O, Fanen P, Verkman AS, Galietta LJ: Altered channel gating mechanism for CFTR inhibition by a high-affinity thiazolidinone blocker. FEBS Lett 2004;558:52-56.

89 Jessen F, Sjoholm C, Hoffmann EK: Identification of the anion exchange protein of Ehrlich cells: a kinetic analysis of the inhibitory effects of 4,4'-diisothiocyano-2,2'-stilbene-disulfonic acid (DIDS) and labeling of membrane proteins with 3H-DIDS. J Membr Biol 1986;92:195-205.

90 Zhang JY, Wu F, Gu XM, Jin ZX, Kong LH, Zhang Y, Zhou JJ, Gao F: The Blockade of Transmembrane $\mathrm{Cl}^{-}$ Flux Mitigates I/R-Induced Heart Injury via the Inhibition of Calpain Activity. Cell Physiol Biochem 2015;35:2121-2134.

91 Shen B, Fu J, Guo J, Zhang J, Wang X, Pan X, Chen M, Zhou Y, Zhu M, Du J: Role of $\mathrm{Na}^{+}-\mathrm{K}^{+}-2 \mathrm{Cl}^{-}$Cotransporter 1 in Phenylephrine-Induced Rhythmic Contraction in the Mouse Aorta: Regulation of $\mathrm{Na}^{+}-\mathrm{K}^{+}-2 \mathrm{Cl}^{-}$ Cotransporter 1 by $\mathrm{Ca}^{2+}$ Sparks and KCa Channels. Cell Physiol Biochem 2015;37:747-758.

92 Barzilay M, Cabantchik ZI: Anion transport in red blood cells. II. Kinetics of reversible inhibition by nitroaromatic sulfonic acids. Membr Biochem 1979;2:255-281.

93 Takeda M, Narikawa S, Hosoyamada M, Cha SH, Sekine T, Endou H: Characterization of organic anion transport inhibitors using cells stably expressing human organic anion transporters. Eur J Pharmacol 2001;419:113-120.

94 Gribble FM, Reimann F: Sulphonylurea action revisited: the post-cloning era. Diabetologia 2003;46:875891.

95 Jabeen T, Singh N, Singh RK, Sharma S, Somvanshi RK, Dey S, Singh TP: Non-steroidal anti-inflammatory drugs as potent inhibitors of phospholipase A2: structure of the complex of phospholipase A2 with niflumic acid at 2.5 Angstroms resolution. Acta Crystallogr D Biol Crystallogr 2005;61:1579-1586. 